Marquette University

e-Publications@Marquette

College of Nursing Faculty Research and

Publications

Nursing, College of

$5-2016$

\title{
Exploring the Pursuit of Doctoral Education by Nurses Seeking or Intending to Stay in Faculty Roles
}

\author{
Kristina Dreifuerst \\ Marquette University, kristina.dreifuerst@marquette.edu \\ Angela M. McNelis \\ George Washington University School of Nursing \\ Michael T. Weaver \\ Duke University \\ Marion E. Broome \\ George Washington University \\ Claire Burke Draucker \\ Indiana University
}

See next page for additional authors

Follow this and additional works at: https://epublications.marquette.edu/nursing_fac

Part of the Nursing Commons

\section{Recommended Citation}

Dreifuerst, Kristina; McNelis, Angela M.; Weaver, Michael T.; Broome, Marion E.; Draucker, Claire Burke; and Fedko, Andrea Stuedemann, "Exploring the Pursuit of Doctoral Education by Nurses Seeking or Intending to Stay in Faculty Roles" (2016). College of Nursing Faculty Research and Publications. 651.

https://epublications.marquette.edu/nursing_fac/651 


\section{Authors}

Kristina Dreifuerst, Angela M. McNelis, Michael T. Weaver, Marion E. Broome, Claire Burke Draucker, and Andrea Stuedemann Fedko 
Marquette University

e-Publications@Marquette

\section{Nursing Faculty Research and Publications/College of Nursing}

This paper is NOT THE PUBLISHED VERSION; but the author's final, peer-reviewed manuscript. The published version may be accessed by following the link in the citation below.

Journal of Professional Nursing, Vol. 32, No. 3 (May/June 2016): 202-212. DOI. This article is (C) Elsevier and permission has been granted for this version to appear in e-Publications@Marquette. Elsevier does not grant permission for this article to be further copied/distributed or hosted elsewhere without the express permission from Elsevier.

\section{Exploring the Pursuit of Doctoral Education by Nurses Seeking or Intending to Stay in Faculty Roles}

Kristina Thomas Dreifuerst

Assistant Professor, Indiana University. Indianapolis, IN

Angela M. McNelis

Professor and Associate Dean for Research and Scholarship, University of Florida, Gainesville, FL Michael T. Weaver

Dean of the School of Nursing; Vice Chancellor for Nursing Affairs, Duke University; and Associate Vice President for Academic Affairs for Nursing, Duke University Health System, Durham, NC

Marion E. Broome

Professor and Associate Dean for Scholarship, Innovation, and Clinical Science, George Washington University, Washington, D.C

Claire Burke Draucker

Angela Barron McBride Endowed Professor, Indiana University, Indianapolis, IN

Andrea S. Fedko

PhD Candidate, Indiana University, Indianapolis, IN 


\begin{abstract}
The purpose of this study was to describe the factors influencing the pursuit and completion of doctoral education by nurses intending to seek or retain faculty roles. Traditionally, doctoral education evolved to focus on the preparation of nurses to conduct scientific research, primarily through the doctor of philosophy programs. Most recently, the doctor of nursing practice degree emerged and was designed for advanced practice nurses to be clinical leaders who translate research into practice and policy. Nurses who pursue doctoral education in order to assume or maintain faculty roles must choose between these degrees if they desire a doctorate within the discipline; however, factors influencing their decisions and the intended outcomes of their choice are not clear. During this study, 548 nurses (current students or recent graduates of doctoral programs) completed a comprehensive survey to generate critical evidence about the factors influencing the choices made. Principal findings are related to the issues of time, money, and program selection. These findings can be used to develop strategies to increase enrollment and, therefore, the number of doctorally prepared faculty who are specifically prepared to excel as nursing faculty.
\end{abstract}

\title{
Index words
}

PhD in nursing, DNP, Doctoral education, Faculty shortage

THE DECISION TO pursue doctoral study is complex and requires potential students to consider multiple factors when making choices. Factors impacting choices include type of program (PhD or Doctor of Nursing, [DNP]), delivery method (on-line, face-to-face, hybrid), structure (rigid or flexible scheduling and progression), faculty expertise and research interests, and the cost and length of program. In addition, personal (family, health, finances) and professional (job security and advancement) factors must also be considered when making the decision to attend a doctoral program. Once admitted and matriculated, doctoral students and recent graduates face significant challenges to their success because of numerous programmatic, personal, and professional stressors. Given the high vacancy rates of doctorally prepared faculty in schools of nursing across the country (American Association of Colleges of Nursing [AACN], 2015), it is important to understand decisions made about initiating and completing doctoral study, including intentions around beginning or staying in faculty roles (IOM, 2011). The purpose of this article is to report the quantitative findings from a mixed-methods, multiphase, multisite study that explored factors influencing the pursuit and completion of doctoral education by nurses intending to seek or retain faculty roles.

\section{Review of the Literature}

According to the AACN (2015), recent survey data demonstrated a national nurse faculty vacancy rate of $6.9 \%$, with $56.4 \%$ of schools reporting full-time vacancies. Almost $58 \%$ of these vacancies were for positions requiring or preferring a doctoral degree. The AACN's report on 2013-2014 enrollment estimated that 78,089 potential students could have been admitted to undergraduate and graduate nursing programs had there been enough nursing faculty available to teach them (AACN, 2014). Many options for addressing the faculty shortage have been discussed in the literature over the past four decades (Allan and Aldebron, 2008, Anderson et al., 1985, Carole, 2002, Danzey et al., 2011; $\underline{\text { Halcomb }}$ 
et al., 2007, McAllister et al., 2014, Nehls and Rice, 2014, Princeton, 1992), yet faculty prepared for the role remain in short supply.

\section{PhD and DNP Degrees}

Despite many degree options, the overall number of doctorally prepared nurses remains low within the discipline. While numbers of DNP students and graduates continue to rise steeply, with a $176 \%$ increase in DNP enrollments between 2007 and 2009, PhD graduates have remained fairly constant during that same time, with a mere 5\% increase from 2008 to 2009 (Fang, Tracy, \& Bednash, 2010). Recent trends, however, indicate that this may be changing. Almost 15,000 nurses were enrolled in DNP programs and over 5,000 in PhD programs in the United States in 2013-14, more than in any of the prior 5 years (Kirschling, 2014).

Nearly all PhD and as many as $60 \%$ of recent DNP graduates assume academic roles upon degree completion, yet their numbers fail to adequately meet the need for nurse educators to replace those expected to leave academe for other roles or to expand student capacity and generate knowledge for the discipline (Altuntas,, 2014, Lewallen and Kohlenberg, 2011, Potempa et al., 2008, Zungolo, 2009). This may be explained by recent research findings from Bednash and Fang (2015) who found that $72 \%$ of current PhD students planned to pursue academic careers after graduating from their programs; however, half of these students were already faculty at the time, so they would not add significantly to the number of total faculty available upon graduation. Moreover, half of the currently active faculty are expected to retire by 2016 (Fang and Bednash, 2014, Robert Wood Johnson Foundation (RWJ), 2007), adding to the urgency of increasing the number of doctorally prepared faculty for the professoriate. Coupled with inconsistent approaches to preparation for faculty role across doctoral programs, the profession is faced with issues of both quantity and quality of nurse faculty educators as the faculty shortage persists (Ramsburg and Childress, 2012, Sebastian and White, 2013). In fact, almost $70 \%$ of schools of nursing reported that a limited pool of doctorally prepared faculty from

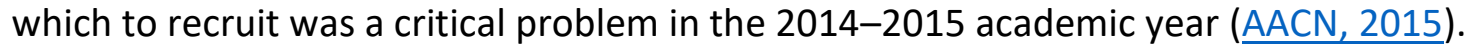

Understanding why and how nurses pursue doctoral education when they are seeking or intending to stay in academic roles and their degree choice ( $\mathrm{PhD}$ or DNP) is important as we prepare the next generation of faculty. The focus of the $\mathrm{PhD}$ is on research methods and knowledge generation ( $\underline{A \mathrm{ACN}}$, 2005), with a curriculum designed to prepare nurses to be independent researchers able to foster a program of research based on scientific inquiry for contribution to the discipline. Coursework and preparation for teaching (i.e., education pedagogy, curriculum, and evaluation) are not part of the essential elements or recommended infrastructure (AACN, 2010) and are inconsistently evident in the PhD programs available in the United States. Despite this, the position of the AACN and the National League for Nursing (NLN) is that educators teaching nursing students should possess a terminal degree (American Association of Colleges of Nursing (AACN), 2005, National League for Nursing (NLN), 2013).

The AACN does not, however, specify requirements for coursework in educational pedagogy, curriculum, and evaluation for either the PhD or the DNP, whereas the NLN does (American Association of Colleges of Nursing (AACN), 2005, National League for Nursing (NLN), 2013).

Furthermore, despite a strong clinical emphasis on the practice of nursing, PhD programs rarely have this as a major focus but instead emphasize the development of nurse-scientists. In response, the focus of the DNP is on an advanced clinical degree with an emphasis on clinical practice and research 
utilization to prepare graduates to assume advanced practice and administrator roles (AACN, 2006). Although DNP graduates could be instrumental in keeping rigorous practice a focal point of education, teaching is not currently an intended trajectory or outcome of completing the DNP program ( $\underline{A A C N}$, 2004). Specifically, pedagogical curriculum and teaching practica are not required and are inconsistently offered as coursework (Sebastian and White, 2013, Zungolo, 2009). Nonetheless, DNP graduates are actively seeking academic positions (American Association of Colleges of Nursing (AACN), 2004, American Association of Colleges of Nursing (AACN), 2006, Minnick et al., 2013, Zungolo, 2009). Further, many schools of nursing with master's-prepared faculty are encouraging or demanding that these faculty seek a doctorate in nursing without specifying a preference for a PhD or DNP nor clearly articulating the intended outcomes associated with attaining the degree; therefore, both are being sought to meet this employment requirement.

The curriculum essentials for both $\mathrm{PhD}$ and DNP programs have minimal requirements for education courses to prepare graduates in learning theory, pedagogy, innovative teaching, or nursing education research (American Association of Colleges of Nursing (AACN), 2004, American Association of Colleges of Nursing (AACN), 2006, Allan and Aldebron, 2008). One unintended consequence of this is that junior faculty report high dissatisfaction with and lack of preparation for the teaching role because of lack of exposure to best practices in teaching, curriculum development, and evaluation (Altuntaș, 2014, Boud and Tennant, 2006, Roughton, 2013). Concomitantly, both junior and senior faculty seek opportunities to expand their research and service responsibilities while decreasing teaching obligations, particularly in institutions where tenure is dependent upon research productivity (Ann-Sherrod et al., 2012, Carole, 2002), further reducing the teaching pool. In addition, experienced nurse educators often seek employment at large, research-focused institutions upon attaining their doctorate because they desire different roles, expectations, and status that are not consistently forthcoming; thus, community colleges and smaller colleges and universities attract and retain a disproportionately low number of doctorally prepared faculty in their prelicensure and graduate programs ( $\underline{\text { Roughton, 2013, Zungolo, }}$ 2009).

\section{Faculty Positions}

Compounding these challenges, academia has not universally embraced DNP graduates for faculty roles requiring a terminal degree. Although faculty positions for DNP-prepared graduates are increasing, they are not commensurate with the supply. Moreover, there continues to be a preference for PhD-prepared faculty over DNP-prepared faculty when a terminal degree is the reference criterion (Lynn, Agger, \& Oermann, 2015). This may be occurring for several reasons. Research preparation at the PhD level in the discipline is understood to include a strong scientific emphasis involving generation, translation, and dissemination of evidence (AACN, 2010), which is the foundation for traditional success in promotion and tenure. DNP programs include a rigorous and scholarly approach to knowledge of the discipline, but it emphasizes practice and translation of evidence over independent research, and a thesis or other formal evidence of scholarship for matriculation is not consistently required by all programs (American Association of Colleges of Nursing (AACN), 2006, Kirkpatrick and Weaver, 2013, Mundinger, 2005). As a result, the skills necessary to succeed and be promoted in some colleges and universities can be more difficult for DNP-prepared faculty (Broome, Riner, \& Allam, 2013). 
Based on these issues, many institutions limit DNP graduates to nontenure track roles with large teaching responsibilities for which their clinically focused doctorate has not prepared them to enact (Danzey et al., 2011). Role strain and stress from a mismatch in expectations, preparation, and support can result in faculty attrition (Altuntas, 2014, Evans, 2013). In response to the shortage of doctorally prepared faculty, many master's and bachelor's-prepared nurses are being recruited to teach despite concerns about deficits in their knowledge and skills related to learning theory, pedagogy, evaluation, and teaching innovations (Allan \& Aldebron, 2008).

With the continued faculty shortage, salaries for nontenure track positions are slowly rising to market demand; however, nontenure track and traditional tenure track salaries remain far below those of nurses in service or industry (McDermid, Peters, Jackson, \& Daly, 2012). Further, the nurse with a master's degree that focused on nursing education who chooses to return for a doctorate struggles to fit into a DNP program with a clinical emphasis that prepares for a practice role (Clinical Nurse Specialist or Nurse Practitioner) rather than the desired teaching role (Zungolo, 2009). Likewise, the alternative of a PhD program with its emphasis on research is not always desired because it does not support a career trajectory of excellence in teaching in comprehensive colleges and universities according to the Carnegie classifications (McDermid et al., 2012). Consequently, many master'sprepared nurses do not seek the recommended terminal degree (Baker et al., 2011, Cronenwett et al., 2011) because there is little incentive to do so.

\section{Preparing Future Faculty}

The Future of Nursing Report recommends doubling the number of nurses with a doctorate by 2020 to add to the numbers of nurse faculty and researchers who can teach nursing students (IOM, 2011). On the surface, this recommendation seems reasonable and could result in an intended outcome of producing greater numbers of doctorally prepared nursing faculty. The advent of the practice-focused DNP has generated a great deal of interest, with new programs opening and enrollment trending upward (Kirschling, 2014). Although the DNP programs will produce more doctorally prepared nurses in less time than many PhD programs (Sebastian \& White, 2013), they do not necessarily address the pressing need for more faculty who can effectively teach students using cutting-edge technologies, innovative pedagogies, and evidence-based teaching practices (Ann-Sherrod et al., 2012, National League for Nursing (NLN), 2013).

Initiatives to address the shortage of doctorally prepared nurses and faculty have included developing educational trajectories in which strong students in bachelor of nursing science programs (BSN) are moved into educational plans where they continue through a PhD (Nehls \& Rice, 2014) or DNP (Brown \& Kaplan, 2011) curriculum. Another option is to accelerate the time-to-degree completion by developing PhD program plans that ensure students complete their degree in 3 to 4 years (Bednash, Breslin, Kirschling, \& Rosseter, 2014). Neither of these initiatives addresses the lack of preparation for teaching in the curricula despite this being a major aspect of the academic role. To address this, some schools of nursing have developed teaching certificate programs that students participate in outside of academic degree requirements; however, these have not been as desired by graduate students or employing schools as intended (Flood \& Powers, 2012).

Despite over 40 years of attention in the literature about the faculty shortage (Allan and Aldebron, 2008, Anderson et al., 1985, Carole, 2002, Danzey et al., 2011; Halcomb et al., 2007, McAllister et al., 
2014, Nehls and Rice, 2014, Princeton, 1992), a "perfect storm" now exists. The discipline needs more doctorally prepared nurse faculty who can effectively teach students. The PhD is the desired degree for academe, but it is time and resource intensive to achieve. The DNP is a popular degree that almost always requires fewer credit hours than a PhD and, thus, less time and lower tuition costs and has produced more graduates relative to PhD programs (AACN, 2015). However, the curriculum blueprint for both doctoral degree options does not include pedagogically focused coursework to prepare future faculty for teaching, a component of the traditional academic tripartite (teaching, research/scholarship, and service) role in many academic institutions. Furthermore, master's-prepared nurse educators can teach in some nursing programs for similar compensation, so they may have little incentive to return to school for additional degrees. Finally, at least half of the existing doctorally prepared faculty are approaching retirement (AACN, 2015). Academe is at a critical juncture, and the need for intervention is high. To effectively address this issue, interventions must be based on evidence around the decisions nurses make to pursue or not pursue doctoral education and a faculty role. This article reports the findings from the survey phase of the study, including time, money, program selection, faculty role, and teaching as the respondents related them to their decisions. Specifically, this study sought to describe the factors influencing the pursuit and completion of doctoral education by nurses intending to seek or retain faculty roles and, if possible, determine benefits, consequences, facilitators, and barriers to the pursuit and completion of doctoral education.

For the purposes of this study, benefits were defined as positive results or outcomes from the pursuit and completion of doctoral education, and consequences were negative results or outcomes as determined by the subjects. Likewise, facilitators, as determined by the subjects, made the pursuit and completion of doctoral education easier, and barriers made it more difficult.

\section{Methods}

Following the National Institutes for Health guidelines for mixed-methods research (Creswell, Klassen, Plano Clark, \& Smith, 2011), this 2-year study used a five-phase, sequential explanatory, descriptive research design with different sample groups to address the research questions. Two of the groups were current doctoral students (PhD and DNP) and recent doctoral graduates (PhD and DNP). The methods and findings from the quantitative survey component of the larger study are reported in this article.

\section{Sample}

After receiving Indiana University Institutional Review Board approval, participants were solicited from seven purposively selected states using cluster random sampling accomplished through dividing the United States into six sections by longitude and latitude to ensure national representation. One state per section was randomly selected (PA, SC, ND, IL, OR, AZ) that represented known rural and urban areas to maximize generalizability and reduce bias. The programs offered in these states had a mixture of undergraduate and graduate nursing programs, with at least one PhD and one DNP program in each state. A seventh state, Idaho, was added to represent the three states in the United States that, at the time of the data collection, did not have a PhD program. All schools of nursing in these states that offered either a PhD, a DNP, or both were included in recruitment. 
Based on a power analysis $(P=.05)$ using the most recent doctoral student and graduate numbers at the time (AACN, 2012), the desired sample size was 300 participants representing three groups: 100 current PhD students, 100 current DNP students, and 100 recent (since 2010) graduates (50 PhD and 50 DNP). Actual numbers of participant responses were higher than anticipated, likely because of high interest by potential subjects and the sampling procedures used: PhD students = 196; DNP students $=202 ; \mathrm{PhD}$ graduates $=75 ;$ and DNP graduates $=75$. Thus, the total sample included 548 participants ( $182 \%$ of targeted sample size).

\section{Current Doctoral Students}

Of the 398 doctoral students responding, the majority were attending a school in Pennsylvania (39\%), Arizona (19\%), or Illinois (15\%) that used an on-line format with some limited required time on campus (54\%). Almost all respondents were female (91\%) and Caucasian (88\%). There was more variability in age, with approximately $15 \%$ between 20 and 29 years, $24 \%$ between 30 and 39, 24\% between 40 and 49, 31\% between 50 and 59 , and $5 \%$ between 60 and 69 . Finally, slightly more than half (55\%) had completed a master's degree with a clinical focus area, $28 \%$ a master's degree in nursing education, and $6 \%$ a master's degree in nursing administration.

\section{Recent Doctoral Graduates}

This group of 150 respondents had a very similar profile to the current students, with the majority having graduated from a school in Pennsylvania (55\%), South Carolina (21\%), or Illinois (13\%) that used an on-line education format for their doctoral program with some required time on campus (54\%). Respondents were predominantly female (94\%) and Caucasian (89\%). Graduates were slightly older than the students, with approximately 5\% between 20 and 29 years, 15\% between 30 and 39, 31\% between 40 and 49, 39\% between 50 and 59, and $8 \%$ between 60 and 69 , with $58 \%$ having completed a prior master's degree with a clinical focus area, 20\% a master's degree in nursing education, and $7 \%$ a master's degree in nursing administration.

\section{Sampling Procedures}

To develop the contact information for potential study subjects, the research assistant for the study, in collaboration with the principal investigator, collated names, e-mail addresses, and locations for board of nursing-accredited programs in nursing schools that offered doctoral programs in each of the seven selected states in the study. A master list was generated and provided to the Indiana University Center for Survey Research (CSR), which then contacted schools of nursing utilizing an electronic solicitation to be part of this study and monitored the process for protection of participants following Family Educational Rights and Privacy Act and Institutional Review Board guidelines.

Schools that agreed to facilitate participation provided current student and recent graduate names and e-mail contact information to the CSR, which stored them in a secure Web base. Some schools of nursing chose not to provide contact information but, instead, forwarded the solicitation letter to their students and recent graduates with an Internet link accessible for study participation. When potential participants accessed the link, they were automatically directed to survey information and assigned a confidential subject number to protect their anonymity when they accessed the survey. The secure electronic system delivered the solicitation letter to potential participants, who consented by completing the survey. Nonresponders were recontacted on day 3 and again invited to respond to 
increase participation rates. On day 4, another replicate e-mail solicitation was sent to new potential participants, and the process repeated itself until at least the desired participant targets were met.

\section{Survey Instrument}

The comprehensive survey was a 92-item, branching by selection, electronic document developed by the researchers and the CSR with data from 19 pilot interviews of master's-prepared nurse educators, current doctoral students (PhD and DNP), and recent (since 2010) graduates. Face validity was established by piloting the survey with nurses who represented the groups of interest but did not meet inclusion criteria for the study based on their location. Items were ranked using a 4-point Likert scale. The survey also included an optional area for written comments, and $58 \%(n=317)$ of the respondents provided one or more written responses to the survey items. Many survey participants also e-mailed the researchers directly (unsolicited) to explain their responses and "share their story." These additional narratives paralleled findings in other phases of the mixed-methods research study.

Data Analysis

Following receipt by the CSR, all data were converted for analysis using SAS Version 9.3 (SAS, 2011). Descriptive statistics appropriate for measurement level were used to evaluate distributions of variable values, patterns of missing data, and presence of out-of-range values. Discrepant values were compared with original data and corrected or set to missing if the discrepancy could not be resolved. Because of the highly skewed response patterns observed for ordered category scaled items and instances of relatively small cell sizes, it was determined that tests of means or medians would be inappropriate. Instead, variables were transformed into dichotomous scales indicating endorsement of the item (no/yes), allowing use of chi-square tests of association with calculation of exact $P$ values for analyses in this article, as implemented in the statistical program (SAS, 2011). Those $P$ values are based on exact conditional inference statistical theory and are appropriate when asymptotically derived $P$ values may not be valid because of sparse, skewed, or heavily tied data distributions (Agresti, 1992). The distributions of selected variables of interest were compared separately for current students (PhD compared with DNP) and recent graduates (PhD compared with DNP). Contingency table analyses, with exact $P$ value calculation, were used for comparisons. Because of the large number of comparisons, an adjusted significance level of $P=.025$ was used to evaluate each comparison. Table 1, Table 2 Table 3 , Table 4 show the comparisons of the percentage of PhD versus DNP students and graduates endorsing each item. Open-ended comments provided by respondents to the survey questions were then reviewed for themes and patterns and associated with the quantitative data. A research team member extracted all text related to the survey questions that had statistical significance and attached short codes (phrases) that captured the essence of the participants' comments. A content-analytic summary table as described by Miles, Huberman, and Saldaña (2014) was used to organize the codes according to the themes (time, money, program confusion, and faculty role) that emerged and the questions to which they referred.

Table 1. Time

\begin{tabular}{|l|l|l|l|l|}
\hline Label & $\begin{array}{l}\text { PhD student } \\
\text { count/\% } \\
\text { endorsing }\end{array}$ & $\begin{array}{l}\text { DNP student } \\
\text { count/\% } \\
\text { endorsing }\end{array}$ & $\begin{array}{l}\text { PhD grad } \\
\text { count/\% } \\
\text { endorsing }\end{array}$ & $\begin{array}{l}\text { DNP grad } \\
\text { count/\% } \\
\text { endorsing }\end{array}$ \\
\hline
\end{tabular}




\begin{tabular}{|c|c|c|c|c|}
\hline $\begin{array}{l}\text { Critical factors when you chose your } \\
\text { doctoral program: There was a part- } \\
\text { time enrollment option. }\end{array}$ & $107 / 61.45$ & $90 / 55.90$ & $36 / 52.18$ & $39 / 60.94$ \\
\hline $\begin{array}{l}\text { Critical factors when you chose your } \\
\text { doctoral program: The program } \\
\text { could be completed in 2-3 years. }\end{array}$ & $42 / 29.58$ & $164 / 84.54$ & $9 / 14.06$ & $66 / 90.41$ \\
\hline $\begin{array}{l}\text { When deciding which doctoral } \\
\text { program(s) you would apply to, were } \\
\text { any of the following critical factors? } \\
\text { How long it takes to finish the } \\
\text { degree. }\end{array}$ & $78 / 44.32$ & $131 / 70.05$ & $24 / 35.29$ & $60 / 84.51$ \\
\hline $\begin{array}{l}\text { Critical factors when you chose your } \\
\text { doctoral program: The pace of the } \\
\text { program could be adjusted for things } \\
\text { like job or family responsibilities. }\end{array}$ & $125 / 70.22$ & $127 / 76.51$ & $48 / 70.59$ & $43 / 65.15$ \\
\hline $\begin{array}{l}\text { I need to work full time while getting } \\
\text { my doctoral degree. }\end{array}$ & $144 / 76.59$ & $156 / 82.11$ & $55 / 80.88$ & $67 / 91.78$ \\
\hline $\begin{array}{l}\text { I receive release time (or anticipate } \\
\text { receiving it) from my employer to } \\
\text { attend a doctoral program. }\end{array}$ & $61 / 31.77$ & $56 / 29.02$ & $23 / 31.94$ & $16 / 21.62$ \\
\hline $\begin{array}{l}\text { How much does each of the } \\
\text { following interfere with studying and } \\
\text { writing while a doctoral student? Job } \\
\text { responsibilities. }\end{array}$ & $162 / 90.02$ & $175 / 92.59$ & $55 / 78.57$ & $62 / 84.93$ \\
\hline $\begin{array}{l}\text { How much does each of the } \\
\text { following interfere with studying and } \\
\text { writing while a doctoral student? } \\
\text { Family responsibilities and other } \\
\text { personal activities. }\end{array}$ & $160 / 84.21$ & $161 / 81.96$ & $51 / 70.83$ & $56 / 76.71$ \\
\hline $\begin{array}{l}\text { My doctoral education is worth the } \\
\text { time commitment to me. }\end{array}$ & $188 / 96.91$ & $191 / 97.95$ & $68 / 93.15$ & $72 / 98.63$ \\
\hline
\end{tabular}

Table 2. Money

\begin{tabular}{|l|l|l|l|l|}
\hline Label & $\begin{array}{l}\text { PhD student } \\
\text { count/\% } \\
\text { endorsing }\end{array}$ & $\begin{array}{l}\text { DNP student } \\
\text { count/\% } \\
\text { endorsing }\end{array}$ & $\begin{array}{l}\text { PhD grad } \\
\text { count/\% } \\
\text { endorsing }\end{array}$ & $\begin{array}{l}\text { DNP grad } \\
\text { count/\% } \\
\text { endorsing }\end{array}$ \\
\hline $\begin{array}{l}\text { My doctoral education is worth } \\
\text { the financial investment to me. }\end{array}$ & $177 / 92.19$ & $182 / 93.33$ & $64 / 87.67$ & $65 / 87.84$ \\
\hline $\begin{array}{l}\text { Doctorally prepared nursing } \\
\text { faculty earn more. }\end{array}$ & $136 / 73.51$ & $111 / 58.73$ & $43 / 60.56$ & $34 / 47.89$ \\
\hline $\begin{array}{l}\text { The difference between in-state } \\
\text { and out-of-state tuition was a } \\
\text { factor when choosing which } \\
\text { doctoral program to attend. }\end{array}$ & $57 / 42.22$ & $108 / 58.28$ & $13 / 26.00$ & $26 / 53.06$ \\
\hline
\end{tabular}




\begin{tabular}{|l|l|l|l|l|}
\hline $\begin{array}{l}\text { Receiving financial aid or support } \\
\text { is essential for me to attend a } \\
\text { doctoral program. }\end{array}$ & $157 / 83.51$ & $158 / 88.76$ & $55 / 80.88$ & $44 / 68.75$ \\
\hline $\begin{array}{l}\text { Were any of the following } \\
\text { financial factors critical to your } \\
\text { decision to attend your doctoral } \\
\text { program: Faculty Nurse Loan } \\
\text { Payment Funding. }\end{array}$ & $96 / 59.37$ & $88 / 42.1$ & $41 / 59.01$ & $30 / 39.48$ \\
\hline
\end{tabular}

Table 3. Program Selection

\begin{tabular}{|c|c|c|c|c|}
\hline Label & $\begin{array}{l}\text { PhD student } \\
\text { count } / \% \\
\text { endorsing }\end{array}$ & $\begin{array}{l}\text { DNP student } \\
\text { count/\% } \\
\text { endorsing }\end{array}$ & $\begin{array}{l}\text { PhD grad } \\
\text { count } / \% \\
\text { endorsing }\end{array}$ & $\begin{array}{l}\text { DNP grad } \\
\text { count/\% } \\
\text { endorsing }\end{array}$ \\
\hline $\begin{array}{l}\text { When you chose where you would } \\
\text { get your doctoral degree, how } \\
\text { important were the following } \\
\text { program factors? Ranking of the } \\
\text { program. }\end{array}$ & $35 / 18.13$ & $30 / 15.31$ & $14 / 19.18$ & $10 / 13.51$ \\
\hline $\begin{array}{l}\text { When you chose where you would } \\
\text { get your doctoral degree, how } \\
\text { important were the following } \\
\text { program factors? The faculty's } \\
\text { research interests. }\end{array}$ & $22 / 11.28$ & 79/39.90 & $10 / 13.89$ & $27 / 37.50$ \\
\hline $\begin{array}{l}\text { Given the choice, I would prefer to } \\
\text { attend: An on-line-only doctoral } \\
\text { program. }\end{array}$ & $62 / 34.25$ & $99 / 51.83$ & $18 / 25.35$ & $45 / 67.16$ \\
\hline $\begin{array}{l}\text { Given the choice, I would prefer to } \\
\text { attend: A doctoral program with } \\
\text { some on-line and some face-to- } \\
\text { face experiences. }\end{array}$ & $137 / 74.05$ & $161 / 83.85$ & $45 / 63.38$ & $54 / 76.06$ \\
\hline $\begin{array}{l}\text { Given the choice, I would prefer to } \\
\text { attend: A traditional face-to-face } \\
\text { doctoral program. }\end{array}$ & $102 / 55.74$ & $65 / 34.03$ & $39 / 55.71$ & $11 / 17.19$ \\
\hline $\begin{array}{l}\text { Critical factors when you chose } \\
\text { your doctoral program: Geographic } \\
\text { convenience. }\end{array}$ & $82 / 42.27$ & $68 / 34.34$ & $28 / 38.89$ & $24 / 32.43$ \\
\hline $\begin{array}{l}\text { How well do you feel your doctoral } \\
\text { education is preparing you in the } \\
\text { following areas: Generating } \\
\text { nursing research. }\end{array}$ & $196 / 100.00$ & $147 / 76.56$ & $69 / 95.83$ & $59 / 80.82$ \\
\hline $\begin{array}{l}\text { Getting a PhD is more difficult than } \\
\text { a DNP. }\end{array}$ & $167 / 89.30$ & $98 / 51.04$ & $71 / 97.26$ & $27 / 38.03$ \\
\hline
\end{tabular}

Table 4. Faculty Role and Teaching 


\begin{tabular}{|c|c|c|c|c|}
\hline Label & $\begin{array}{l}\text { PhD } \\
\text { student } \\
\text { count/\% } \\
\text { endorsing }\end{array}$ & $\begin{array}{l}\text { DNP } \\
\text { student } \\
\text { count/\% } \\
\text { endorsing }\end{array}$ & $\begin{array}{l}\text { PhD grad } \\
\text { count } / \% \\
\text { endorsing }\end{array}$ & $\begin{array}{l}\text { DNP grad } \\
\text { count } / \% \\
\text { endorsing }\end{array}$ \\
\hline $\begin{array}{l}\text { Please indicate your current position(s). } \\
\text { Full-time faculty }\end{array}$ & $98 / 52.13$ & $130 / 72.22$ & $18 / 25$ & $50 / 68.50$ \\
\hline $\begin{array}{l}\text { Please indicate your current position(s). } \\
\text { Part-time faculty }\end{array}$ & $172 / 91.49$ & $169 / 93.89$ & $70 / 97.22$ & $69 / 94.52$ \\
\hline Are you currently teaching? & $127 / 65.13$ & $73 / 36.87$ & $61 / 84.72$ & $44 / 59.46$ \\
\hline $\begin{array}{l}\text { Did you begin your doctoral program with } \\
\text { the intent of becoming a doctorally } \\
\text { prepared nursing educator? }\end{array}$ & $154 / 79.38$ & $98 / 50.26$ & $63 / 86.30$ & $34 / 45.95$ \\
\hline $\begin{array}{l}\text { Was this a critical factor when you chose } \\
\text { your doctoral program? }\end{array}$ & $130 / 77.38$ & $101 / 52.17$ & $52 / 81.25$ & $28 / 53.85$ \\
\hline $\begin{array}{l}\text { How many courses related to the faculty } \\
\text { role do you plan/did you take in your } \\
\text { doctoral program? At least one not more } \\
\text { than two. }\end{array}$ & $67 / 41.61$ & $33 / 23.40$ & $72 / 24.98$ & $68 / 34.69$ \\
\hline $\begin{array}{l}\text { Of those courses, what was the focus? } \\
\text { Tripartite role }\end{array}$ & $90 / 77.84$ & $2 / 1.79$ & $68 / 73.51$ & $2 / 3.01$ \\
\hline $\begin{array}{l}\text { Of those courses, what was the focus? } \\
\text { Teaching role (curriculum, evaluation, and } \\
\text { teaching practicum) }\end{array}$ & $23 / 22.94$ & $30 / 20.97$ & $30 / 25.62$ & $66 / 30.98$ \\
\hline $\begin{array}{l}\text { How much the following aspects of } \\
\text { doctoral education interest(ed) you while } \\
\text { pursuing your doctoral degree. Taking } \\
\text { teaching courses (curriculum, evaluation, } \\
\text { and teaching practicum). Very much }\end{array}$ & $162 / 83.94$ & $137 / 70.98$ & $70 / 95.89$ & $35 / 47.95$ \\
\hline $\begin{array}{l}\text { How well do you feel your doctoral } \\
\text { education is preparing/prepared you in } \\
\text { the following areas: Assuming a nursing } \\
\text { faculty role }\end{array}$ & $166 / 86.91$ & $134 / 68.72$ & $60 / 82.19$ & $55 / 75.34$ \\
\hline $\begin{array}{l}\text { Do you/did you plan to focus your } \\
\text { coursework and } \\
\text { dissertation/thesis/project on topics } \\
\text { related to nursing education? }\end{array}$ & $69 / 35.94$ & $53 / 27.32$ & $34 / 46.57$ & $28 / 37.84$ \\
\hline $\begin{array}{l}\text { A doctoral education is necessary to be a } \\
\text { good: Nurse educator }\end{array}$ & $156 / 82.98$ & $150 / 78.12$ & $55 / 76.38$ & $59 / 80.82$ \\
\hline
\end{tabular}

\section{Findings and Discussion}

Four concepts were predominant across survey responses: (a) time, (b) money, (c) program/program confusion, and (d) faculty role. These concepts, although often intertwined, described the relationships among choices nurses make about doctoral education, preparation for teaching during doctoral study, and perceptions of an academic career in nursing. 


\section{Time}

The concept of time meant different things to doctoral students and recent graduates (Table 1). Time was a critical factor when choosing a doctoral program; however, only $61 \%$ of $\mathrm{PhD}(n=107)$ and $56 \%$ of DNP $(n=90)$ students and $52 \%$ of PhD $(n=36)$ and $61 \%$ of DNP $(n=39)$ graduates endorsed a parttime option as having been important in their decision. This was an interesting finding because $75 \%$ of the current PhD $(n=147)$ and $70 \%$ of the current DNP $(n=141)$ students indicated that they were parttime students.

Time for degree completion was relatively less important for PhD students and graduates than their DNP colleagues. Approximately $30 \%$ of $\operatorname{PhD}(n=142)$ and $85 \%$ of DNP $(n=164)$ students and $14 \%$ of $\mathrm{PhD}(n=9)$ and $90 \%$ of DNP $(n=66)$ graduates said that it was important that their doctoral program could be completed within 2 to 3 years. This is an important finding that needs further consideration given recent federal funding initiatives stipulating that $\mathrm{PhD}$ programs be completed within 3 years. The majority (71\%) of all respondents believed, however, that it was critical that the pace of their doctoral program could be adjusted by changing credits taken and course load or by sequencing courses in any needed semester to address issues such as job or family responsibilities. The reasons for these differences in the perspectives of students and graduates related to time to finish the degree (in and out of state) need further longitudinal investigation.

The concepts of time and funding did overlap. Most of the respondents reported that they needed to work full time while getting their doctoral degree, despite the fact that $91 \%$ said that they were receiving financial aid (Table 1). Few were receiving release time from their job, yet most said that they would welcome it. This may be because almost all survey participants reported that job and family responsibilities interfered with studying and writing (Table 1). Most respondents ( $80 \%$ of students and $71 \%$ of recent graduates in both programs) reported that they had children at home, further adding to the tensions about time management cited by many of the participants. Nonetheless, $97 \%$ of PhD $(n=188)$ and $98 \%$ of DNP $(n=191)$ students and $93 \%$ of PhD $(n=68)$ and $99 \%$ of DNP $(n=72)$ graduates reported that their doctoral education was worth the time commitment (Table 1).

All of these findings should be carefully considered when implementing doctoral programs that require students to be full time or to take a particular number of credits per semester. Clearly, these respondents provide evidence that such requisites are not possible to adhere to or preferred by all students. Furthermore, the desire of respondents in this study to have paid release time as an incentive to pursuing doctoral education may be a useful way to address both time and money concerns when recruiting doctoral students and incenting existing faculty to obtain the terminal degree.

\section{Money}

Money was an equally important consideration for nurses considering doctoral education from three perspectives: (a) paying for their education, (b) (potential) return on investment, and (c) impact on their salary after graduation (Table 2). Two thirds of all participants considered cost a major factor in deciding which program to attend; however, only $42 \%$ of PhD $(n=57)$ and $58 \%$ of DNP $(n=108)$ students and $26 \%$ of PhD $(n=13)$ and $53 \%$ of DNP $(n=26)$ graduates indicated that the difference between in-state and out-of-state tuition had been a factor when choosing which program to attend. 
Many survey respondents provided comments explaining this. Both PhD students and graduates reported that programs that fit their academic goals were not always available in-state, and recent DNP graduates wrote about how the landscape of program offerings had been different when they were selecting a program, with significantly fewer options to choose from at that time as compared with today. As a result, respondents in both groups mentioned that they would likely choose equivalent options in-state and local when available, given the difference in tuition costs; however, they would not have chosen an in-state program if it did not offer the academic program they were looking for, despite cost savings. The majority of DNP students (77\%) were attending in-state programs versus $31 \%$ of PhD students. These findings were not surprising and may be related to the fact that many states have only a few PhD programs within their borders to choose from, although the number of states with multiple DNP programs continues to rise.

Other comments focused on postgraduation salary expectations and realities. This may be related to the fact that a salary increase was not experienced by everyone following degree completion. Only $61 \%$ of $\mathrm{PhD}(n=43)$ and $48 \%$ of DNP $(n=34)$ graduates reported having actually received a raise, although $74 \%$ of PhD $(n=136)$ and $59 \%$ of DNP $(n=111)$ students expected a significant salary increase after completing their degree. There was a general expectation that their investment in tuition would be compensated with significantly higher salaries after graduation, yet most graduates said that their increase, if any, had been modest and did not meet what they anticipated. Faculty salaries have been discussed extensively in the literature (Fang et al., 2010b, Nardi and Gyurko, 2013) and may not ever meet students' expectations. However, return on investment can be achieved in other creative ways, and this needs further exploration.

The ability to access and use Nurse Faculty Loan Program (HRSA) money was a critical factor in deciding to pursue doctoral education for approximately $60 \%$ of PhD current students and recent graduates and $40 \%$ of DNP students and recent graduates (Table 2). Almost $85 \%$ of all respondents indicated that they had participated in the NFLP or a similar one administered by states or private entities. Federal and state government officials need this feedback so that continued funding for these programs will be a budget priority. Moreover, because the dependence on financial assistance continues, particularly with the higher costs of out-of-state tuition, creative programs to address the financial burden of doctoral education will also be necessary to entice nurses into the programs as costs rise.

Finally, in the survey, about $92 \%$ of current students in both programs said that the money spent on their education was worth the cost. However, in the written comments, current students and recent graduates of both programs questioned if the investment of time and money would pay off during their careers. This may reflect the age of the participants and the relatively short period left in an active career to recoup their investment $(59 \%[n=326]$ of all respondents were between 40 and 59 years old). Even so, a large majority of all respondents believed that their doctoral education was worth the financial investment (Table 2).

\section{Program Selection}

Data regarding program characteristics perceived as factors that had influenced decisions about the pursuit and completion of doctoral education were less consistent than money or time factors. Most participants did not endorse geographic location as having been a significant consideration when choosing a program (Table 3 ). There was also not a significant preference for traditional face-to-face 
programs versus on-line by any of the respondent groups. Further, $74 \%$ of $\mathrm{PhD}(n=137)$ and $84 \%$ of DNP $(n=161)$ students and $63 \%$ of PhD $(n=45)$ and $76 \%$ of DNP $(n=54)$ graduates indicated that their preference for course delivery had been a hybrid that included some on-line and some face-to-face experiences. In the written comments, many stated that, although the on-line delivery was necessary and preferred because it fit best with their busy lives, some occasional face-to-face opportunities throughout the year were important to develop relationships with fellow students and faculty. Respondents noted that these relationships were facilitators of their success.

The survey responses related to program delivery were predictable. The popularity of on-line graduate education continues to be evident (Erichsen, Bolliger, \& Halupa, 2014), and respondents indicated high regard for it as long as there were some residence experiences on campus to foster relationships with other students and faculty. This is currently a common model in doctoral education; however, further investigation into optimal frequency and duration of in-person intensives or on-campus residence experiences to promote student learning and success is needed.

Data in this study revealed some surprises about programs and choices nurses make about doctoral education when they are pursuing or intending to stay in faculty roles. Only $18 \%$ of $\mathrm{PhD}(n=35)$ and $15 \%$ of DNP $(n=30)$ students and $19 \%$ of PhD $(n=14)$ and $14 \%$ of DNP $(n=10)$ graduates had considered the ranking of the school when deciding on a doctoral program. Further, only $11 \%$ of PhD $(n=22)$ and $40 \%$ of DNP $(n=79)$ students and $14 \%$ of PhD $(n=10)$ and $38 \%$ of DNP $(n=27)$ graduates had considered the faculty's research interests or expertise when choosing their doctoral program (Table 3). This is an important finding as school ranking and faculty research interests are emphasized by schools recruiting into their programs. The relevance of these to student success and graduate role preparation may need to be explicated further to influence the choices potential students are making related to program selection, so that fit with a faculty mentor is a priority in the decision-making process.

There also appeared to be a lack of clarity about the differences between the PhD and DNP degrees: $89 \%$ of $\mathrm{PhD}(n=167)$ and $51 \%(n=98)$ of DNP students said getting a PhD is more difficult than a DNP, and $97 \%(n=71)$ of PhD but only $38 \%(n=27)$ of DNP graduates endorsed this difference. However, the majority of DNP students and graduates also reported that they had chosen the DNP because the program required fewer credits for completion. Similarly, in the written comments, DNP participants repeatedly shared their belief that the DNP was the "easier, faster, cheaper" route to a doctoral degree. A number of those commenting also stated that this was important because a doctorate was necessary to obtain or maintain their faculty role, yet the type of degree was not specified. Therefore, the DNP participants stated that they had chosen what they assumed to be the "path of least resistance" without consideration of how the coursework would prepare them for this role.

Confusion related to the purposes, competencies, and outcomes of the different doctoral degrees was also evident from the finding that $22 \%$ of $\mathrm{PhD}$ graduates said they had begun their doctoral program with the intent of becoming a nursing clinician, whereas $13 \%$ of DNP graduates said that they had begun their doctoral program with the intent of becoming a nursing researcher. Less than half of the DNP graduates began the program with the intent of becoming a nursing educator, yet at the time of the survey, $86 \%$ intended to continue in or pursue a faculty role upon graduation. Finally, all of the PhD and $77 \%$ of DNP $(n=147)$ students $96 \%$ of PhD $(n=69)$ and $81 \%$ of DNP $(n=59)$ graduates responding 
to the survey believed that their doctoral program prepared them extremely well to generate nursing research (Table 3 ).

\section{Faculty Role and Teaching}

All but four of the survey participants were already in either full-time or part-time faculty roles, and a majority was currently teaching at the time of the survey. Some had been teaching for many years, and others were new to the role (Table 4). Approximately $21 \%$ of current doctoral students and $20 \%$ of graduates had a master's degree with a focus in nursing education. Further, $79 \%$ of $\mathrm{PhD}(n=154)$ and $50 \%$ of DNP $(n=98)$ students and $86 \%$ of PhD $(n=63)$ and $46 \%$ of DNP $(n=34)$ graduates said that they intended to become doctorally prepared nurse educators when they started their doctoral program, but almost half of the written comments associated with this question indicated dissatisfaction with how their program was preparing them for the faculty role.

This incongruity between the expectations of the degree and the actual experience related to competencies could be related to the fact that $42 \%$ of PhD $(n=67)$ and $23 \%$ of DNP $(n=33)$ students and $25 \%$ of $\mathrm{PhD}(n=72)$ and $35 \%$ of DNP $(n=68)$ graduates reported taking at least one but not more than two courses in their curriculum preparing them for the faculty role. The confusion can further be seen in the responses associated with this coursework. The majority of PhD students $(78 \%, n=90)$ and graduates $(74 \%, n=68)$ said that their coursework focused on the tripartite faculty role, whereas, only $2 \%$ of DNP students $(n=2)$ and $3 \%$ of graduates $(n=2)$ said that their coursework had done this. In contrast, $23 \%$ of $\mathrm{PhD}(n=23)$ and $21 \%$ of DNP $(n=30)$ students and $26 \%$ of $\mathrm{PhD}(n=30)$ and $31 \%$ of DNP $(n=66)$ graduates said coursework was focused on teaching (curriculum, instruction, evaluation, and teaching practicum).

In the comments, most DNP students said their coursework in teaching was either an elective or part of a teaching certificate they were taking external to their DNP degree requirements to prepare for a teaching role. They voiced their frustration with having to do so because these courses were not generally a part of the common curriculum where they had anticipated finding this curriculum. They also expressed concern that they may not be well prepared to assume the faculty role. PhD students and graduates noted that the emphasis on the tripartite role in their coursework was necessary and important. However, even experienced teachers discussed wanting more coursework at the doctoral level related to teaching practice.

\section{Conclusion}

Despite the study findings, the majority of graduates believed that their doctoral education prepared them well to assume a nursing faculty role. In fact, just under half of all respondents indicated their dissertation/thesis or DNP project would be/had been focused on topics related to nursing education. Similarly, about $75 \%$ of those responding said that a doctoral education is necessary to be a good nurse educator (Table 4). Finally, almost all participants strongly endorsed the assertion that doctoral preparation was associated with more power, prestige, and responsibility in a faculty role. Yet, close to half of the DNP and PhD graduates had continued in the same position with the same duties after graduation that they held when they began doctoral studies.

Overwhelmingly, survey participants in both types of doctoral programs identified concerns about their education because it related to preparation for nursing faculty roles and teaching students. Although 
neither the PhD nor the DNP curriculum essentials include content on teaching or faculty roles (American Association of Colleges of Nursing (AACN), 2006, American Association of Colleges of Nursing (AACN), 2010), there is currently a great need for more doctorally prepared faculty (IOM, 2011). All survey respondents (students and graduates) indicated that they were looking for doctorallevel coursework related to both faculty roles and teaching as a part of their program whether they were currently practicing teachers or had had previous master's coursework in teaching and pedagogy.

As more nurses desire to become doctorally prepared faculty, programs need to ensure that they are preparing their graduates to be successful in all of the areas that comprise the faculty role, including teaching, research/scholarship, and service. Preparation to generate knowledge or apply it in practice remains paramount to doctoral education. However, given that significant numbers of graduates assume faculty roles, doctoral-level coursework preparing for academic roles is also important.

Recent innovations in doctoral education have focused on getting students through programs faster as the solution to the shortage of doctorally prepared faculty, but that solution is not supported by the evidence. Rather, focusing on the scope of the curriculum and if/how it prepares students for the roles they will assume after graduation is the critical component that needs to be addressed. Findings from this study reveal that providing curriculum related to both teaching and faculty roles to all doctoral students is an opportunity to address the shortage by preparing students who have never taught, for a future in academe. In addition, offering those who do have teaching experience coursework at the doctoral level will further prepare them for success as they move into doctorally prepared faculty roles. This curriculum enhancement could positively impact the choices nurses make about doctoral education when they are pursuing or intending to stay in faculty roles. It could also be a strategic component for addressing the need for adequate numbers of doctorally prepared faculty in the future and ensure that nursing students benefit from the opportunity to learn from faculty who have had coursework in pedagogical curriculum and have experienced teaching practica.

\section{Limitations}

Several limitations to this study bear consideration. Although the sampling procedure was designed to be representative across the United States, it is possible that regional differences prevalent in the states that were randomly chosen may have skewed the data. Second, survey respondents selfselected to participate in this study and, thus, could represent a biased group. Because there is no information about those who chose not to participate, the sample may not be representative. In addition, given the current diversity and evolving nature of DNP programs, the findings may not hold true for future DNP students and graduates. Finally, the data were retrospective and self-reported. Longitudinal prospective studies could add more certainty to findings associated with causal relationships.

\section{Implications}

Substantial data were obtained from survey respondents in this study, much of which may be of interest to deans, program directors, and faculty in doctoral programs. The large and representative sample provided unique perspectives that would not be as apparent through the lens of a single school or program but may be useful for recruitment and retention of future students and the preparation of faculty. The data point to several opportunities for change within existing doctoral programs and 
structures to increase both the number and quality of doctorally prepared nurses and the number of doctorally prepared nursing faculty.

\section{Future Research}

This was a large, mixed-methods, multiphase, multisite study, although the findings only begin to reveal underlying issues in doctoral education within the discipline that have led to current nursing faculty shortages and low percentages of doctorally prepared nurses. Replicate studies in different geographic locations or configurations are encouraged to broaden the data available about doctoral education in the United States. Further research into the perceptions of doctoral education by potential students, current students, and recent graduates is likewise needed to add breadth and depth to our understanding of this phenomenon. Additional research into the impact of interventions used to increase the number of doctorally prepared nurses is also needed. Finally, longitudinal research looking at the impact of including coursework in pedagogy and instruction in doctoral coursework for both PhD and DNP students would provide outcome data that are not currently available. The shortage of doctorally prepared nurses and, particularly, faculty has reached a critical point. It is incumbent on the profession to devote the necessary resources to develop evidence-based strategies to address this crisis and ensure a continued pipeline of high-quality practitioners needed to deliver health care to our citizens.

\section{Acknowledgments}

This research study was supported in part by a grant from The Robert Wood Johnson

Foundation, Evaluating Innovations in Nursing Education Program, Cycle 3.

\section{References}

Agresti, 1992. A. Agresti. A survey of exact inference for contingency tables. Statistical Science, 7 (1992), pp. 131-177

Allan and Aldebron, 2008. J.D. Allan, J. Aldebron. A systematic assessment of strategies to address the nursing faculty shortage, U.S. Nursing Outlook, 56 (2008), pp. 286-297

Altuntaş, 2014. S. Altuntaş. Factors affecting the job satisfaction levels and quit intentions of academic nurses. Nurse Education Today, 34 (2014), pp. 513-519

American Association of Colleges of Nursing, 2012. American Association of Colleges of Nursing. 20112012 Enrollment and graduations in baccalaureate and graduate programs in nursing. Author, Washington, DC (2012)

American Association of Colleges of Nursing, 2014. American Association of Colleges of Nursing. 20132014 Enrollment and graduations in baccalaureate and graduate programs in nursing. Author, Washington, DC (2014)

American Association of Colleges of Nursing, 2015. American Association of Colleges of Nursing. Special survey on vacant faculty positions for academic year 2014-2015. Retrieved from http://www.aacn.nche.edu/leading-initiatives/research-data/vacancy14.pdf (2015)

American Association of Colleges of Nursing (AACN), 2004. American Association of Colleges of Nursing (AACN). [Position statement] The practice doctorate in nursing. Retrieved from: http://www.aacn.nche.edu/DNP/DNPPositionStatement.htm (2004) 
American Association of Colleges of Nursing (AACN), 2005. American Association of Colleges of Nursing (AACN). [White paper] Faculty shortages in baccalaureate and graduate nursing programs:

Scope of the problem and strategies for expanding the supply. (2005)

American Association of Colleges of Nursing (AACN), 2006. American Association of Colleges of Nursing

(AACN). [Position statement] The essentials of doctoral education for advanced nursing practice. Retrieved from

http://www.aacn.nche.edu/publications/position/DNPEssentials.pdf (2006)

American Association of Colleges of Nursing (AACN), 2010. American Association of Colleges of Nursing

(AACN). [Position statement] The research focused doctoral program in nursing. Retrieved

from: http://www.aacn.nche.edu/education-resources/PhDPosition.pdf (2010)

Anderson et al., 1985. E. Anderson, P. Roth, I.S. Palmer. A national survey of the need for doctorally

prepared nurses in academic settings. Journal of Professional Nursing, 1 (1985), pp. 23-33

Ann-Sherrod et al., 2012. R. Ann-Sherrod, R. Houser, B. Odom-

Bartel, D. Packa, V. Wright, L. Dunn, ..., S. Tomlinson. Creating a successful environment for

preparing doctoral-level nurse educators. The Journal of Nursing Education, 51 (2012), pp. 481488

Baker et al., 2011. S.L. Baker, J.J. Fitzpatrick, M.Q. Griffin. Empowerment and job satisfaction in associate degree nurse educators. Nursing Education Perspectives, 32 (2011), pp. 234-239

Bednash et al., 2014. G. Bednash, E.T. Breslin, J.M. Kirschling, R.J. Rosseter. PhD or DNP planning for doctoral nursing education. Nursing Science Quarterly, 27 (2014), pp. 296301, 10.1177/0894318414546415

Bednash and Fang, 2015. G. Bednash, D. Fang. Identifying barriers and facilitators to nurse faculty careers for doctoral nursing students. Paper presented at AACN Doctoral Education Conference, Coronado, CA (2015)

Boud and Tennant, 2006. D. Boud, M. Tennant. Putting doctoral education to work: Challenges to academic practice. Higher Education Research \& Development, 25 (2006), pp. 293-306 (Article)

Broome et al., 2013. M.E. Broome, M.E. Riner, E.S. Allam. Scholarly publication practices of doctor of nursing practice-prepared nurses. Journal of Nursing Education, 52 (2013), pp. 429-434(PMID: 23855342)

Brown and Kaplan, 2011. M.A. Brown, L. Kaplan. Faculty perspectives about the DNP: A study of advocacy, ambivalence, \& antagonism. The Nurse Practitioner, 36 (2011), pp. 36-44

Carole, 2002. A. Carole. Nursing faculty-Going, going, gone. Nursing Outlook, 50 (2002), pp. 4344, 10.1067/mno.2002.123582

Creswell et al., 2011. J.W. Creswell, A.C. Klassen, V.L. Plano Clark, K.C. Smith. Best practices for mixed methods research in the health sciences. Office of Behavioral and Social Sciences Research, National Institutes for Health, Bethesda, MD (2011)

Cronenwett et al., 2011. L. Cronenwett, K. Dracup, M. Grey, L. McCauley, A. Meleis, M. Salmon. The doctor of nursing practice: A national workforce perspective. Nursing Outlook, 59 (2011), pp. 9-17

Danzey et al., 2011. I.M. Danzey, E. Ea, J.J. Fitzpatrick, S.J. Garbutt, M. Rafferty, M.E. Zychowicz. The doctor of nursing practice and nursing education: Highlights, potential, and promise. Journal of Professional Nursing, 27 (2011), pp. 311-314

Erichsen et al., 2014. E.A. Erichsen, D.U. Bolliger, C. Halupa. Student satisfaction with graduate supervision in doctoral programs primarily delivered in distance education settings. Studies in Higher Education, 39 (2014), pp. 321-338 
Evans, 2013. J.D. Evans. Factors influencing recruitment and retention of nurse educators reported by current nurse faculty. Journal of Professional Nursing, 29 (2013), pp. 11-20

Fang and Bednash, 2014. D. Fang, G.D. Bednash. Attrition of full-time faculty from schools of nursing with baccalaureate and graduate programs, 2010 to 2011. Nursing Outlook, 62 (2014), pp. 164-173

Fang et al., 2010a. D. Fang, C. Tracy, G.D. Bednash. 2009-2010 Enrollment and graduations in baccalaureate and graduate programs in nursing. American Association of Colleges of Nursing, Washington, DC (2010)

Fang et al., 2010b. D. Fang, C. Tracy, G. Bednash. 2009-2010 Salaries of instructional and administrative nursing faculty in baccalaureate and graduate programs in nursing. American Association of Colleges of Nursing, Washington, DC (2010)

Flood and Powers, 2012. L.S. Flood, M.E. Powers. Lessons learned from an accelerated post-master's nurse educator certificate program: Teaching the practicum course. Nursing Education Perspectives, 33 (2012), pp. 40-44, 10.5480/1536-5026-33.1.40

Halcomb et al., 2007. K.A. Halcomb, A.L. Gregg, B. Roberts. Implementing supportive strategies to retain nurse educators. Teaching and Learning in Nursing, 2 (2007), pp. 133-137

IOM (Institute of Medicine), 2011. IOM (Institute of Medicine). The future of nursing: Leading change, advancing health. The National Academies Press, Washington, DC (2011)

Kirkpatrick and Weaver, 2013. J.M. Kirkpatrick, T. Weaver. The doctor of nursing practice capstone project: Consensus or confusion? The Journal of Nursing Education, 52 (2013), pp. 435-441

Kirschling, 2014. J.M. Kirschling. Reflections on the future of doctoral programs in nursing. Paper presented at AACN Doctoral Education Conference (2014). (Retrieved from: http://www.aacn.nche.edu/dnp/JK-2014-DNP.pdf)

Lewallen and Kohlenberg, 2011. L.P. Lewallen, E. Kohlenberg. Preparing the nurse scientist for academia and industry. Nursing Education Perspectives, 32 (2011), pp. 22-25

Lynn et al., 2015. M.R. Lynn, C. Agger, M.H. Oermann. Hiring practices and intentions of directors of nursing programs related to DNP and PhD-prepared faculty. Paper presented at AACN Doctoral Education Conference, Coronado, CA (2015)

McAllister et al., 2014. M. McAllister, F. Oprescu, C. Jones. N2E: Envisioning a process to support transition from nurse to educator. Contemporary Nurse, 46 (2014), pp. 242-250

McDermid et al., 2012. F. McDermid, K. Peters, D. Jackson, J. Daly. Factors contributing to the shortage of nurse faculty: A review of the literature. Nurse Education Today, 32 (2012), pp. 565-569

Miles et al., 2014. M.B. Miles, A.M. Huberman, J. Saldaña. Qualitative data analysis: A methods sourcebook. Sage, Washington, DC (2014)

Minnick et al., 2013. A.F. Minnick, L.D. Norman, B. Donaghey. Defining and describing capacity issues in U.S. doctor of nursing practice programs. Nursing Outlook, 61 (2013), pp. 93-101

Mundinger, 2005. M. Mundinger. Who's who in nursing: Bringing clarity to the doctor of nursing practice. Nursing Outlook, 53 (2005), pp. 173-176

Nardi and Gyurko, 2013. D.A. Nardi, C.C. Gyurko. The global nursing faculty shortage: Status and solutions for change. Journal of Nursing Scholarship, 45 (2013), pp. 317-326

National League for Nursing (NLN), 2013. National League for Nursing (NLN). [Position statement] A vision for doctoral preparation for nurse educators. Retrieved from http://www.nln.org/aboutnln/livingdocuments/pdf/nlnvision_6.pdf (2013)

Nehls and Rice, 2014. N. Nehls, E. Rice. Early entry to a doctoral degree in nursing program: Analysis of student experiences. The Journal of Nursing Education, 4 (2014), pp. 1-6 
Potempa et al., 2008. K.M. Potempa, R.W. Redman, C.A. Anderson. Capacity for the advancement of nursing science. Journal of Professional Nursing, 24 (2008), pp. 329-336

Princeton, 1992. J.C. Princeton. Teacher crisis in nursing education revisited. Nurse Educator, 17 (1992), pp. 34-37

Ramsburg and Childress, 2012. L. Ramsburg, R. Childress. An initial investigation of the applicability of the Dreyfus skill acquisition model to the professional development of nurse educators. Nursing Education Perspectives, 33 (2012), pp. 312-316

Robert Wood Johnson Foundation (RWJ), 2007. Robert Wood Johnson Foundation (RWJ). Charting nursing's future. Retrieved from http://www.rwjf.org/files/publications/other/nursingfuture4.pdf (2007)

Roughton, 2013. S.E. Roughton. Nursing faculty characteristics and perceptions predicting intent to leave. Nursing Education Perspectives, 34 (2013), pp. 217-225

SAS Institute Incorporated (SAS), 2011. SAS Institute Incorporated (SAS). SAS/STAT ${ }^{\circledR} 9.3$ User's Guide. SAS Institute Inc, Cary, NC (2011)

Sebastian and White, 2013. J.G. Sebastian, D.C. White. Doctor of nursing practice programs: Opportunities for faculty development. The Journal of Nursing Education, 52 (2013), pp. 453461

Zungolo, 2009. E. Zungolo. The DNP and faculty role: Issues and challenges. Paper presented at the Second National Conference on the Doctor of Nursing Practice, Hilton Head, SC, March, 2010 (2009) 